SHS Web of Conferences 12, 01015 (2014)

DOI: $10.1051 /$ shsconf/ 20141201015

(C) Owned by the authors, published by EDP Sciences, 2014

\title{
Analysis of Tourism Resource Dependency on Collaboration among Local Governments in the Multi-Regional Tourism Development
}

\author{
Dong-Won $\mathrm{Ha}^{1}$, Seung-Dam Choi ${ }^{2}$, Yeon-Kyung Kwon ${ }^{3}$, Hyun-Jung Kim ${ }^{4}$ \\ ${ }^{1,2,3,4}$ Department of Tourism, Hanyang University, Seoul, South Korea
}

\begin{abstract}
The purpose of this study was to derive the multidimensional attributes of resource dependency of local governments in multi-regional tourism development. The questionnaire was designed based on resource dependence theory and related literature, and five factors of resource dependency were derived by analysis of the questionnaire for the civil servants who participated in the Jirisan area tourism development project which is a representative multi-regional tourism development project of Korea. The measured values of the derived possession, importance, discretion, alternative, and connection were found in various ways according to the project characteristics such as project scale and visitors in the Jirisan area tourism development project. This shows that a variety of variables have an effect on resource dependency.
\end{abstract}

\section{Introduction}

There is an increasing need for cooperation among local governments in tourism development [12, 16$18,29]$. It is necessary to understand the important factors related to this. One of these important factors is the resource dependency of organizations. This is defined as the dependency on other organizations for resources required for survival and operation of the organization. This is an important concept for understanding cooperation between local governments because it determines organizational cooperative behavior [23].

The aim of this study was to derive multidimensional attributes of preferentially required resource dependency for understanding the resource dependency of local governments in multiregional tourism development cooperation. For this purpose, this study aims to derive the factors of resource dependency based on the analysis of the resource dependence theory and related literature and a questionnaire for the local governments involved in the Jirisan area tourism development project which is a representative multi-regional tourism development project of Korea. In addition, it aims to analyze the measured values of each derived factor and to explore the implications of the results of the empirical analysis. 


\section{Theoretical Considerations}

\subsection{Resource Dependence Theory and Resource Dependency}

The resource dependence theory proposed by Pfeffer \& Salancik [24] descries the relationship between organizational resource dependence and cooperation between organizations [20]. They have become increasingly dependent on external resources by obtaining or using insufficient resources from the outside in order to achieve their goals because organizations never can be self-sufficient in all resources required for survival and operation. As a result, interorganizational collaboration is implemented in the form of exchange of information, strategic alliance, partnership, and merger. This theory has been actively studied in interorganizational collaboration. Skinner, Gassenheimer \& Kelley [30] confirmed that there was a positive correlation between dependency and cooperation by using variables such as dependency, power, cooperation, conflict, and satisfaction for dealers of agricultural and electrical equipment.

Park, Jung, \& Lee [22] clarified the relation between resource dependency and cooperation by analyzing that manufacturers' dependence on private brand (PB) had an effect on the long-term relationship between them and distributors. Moreover, in studies on cooperation between governmental organizations, Aldrich [2], Scharpf [27] analyzed the resource-dependent characteristics of organizations by classifying them as interdependence, general dependence and mutual independence according to the level of interorganizational dependency with the use of an interorganizational dependency model $[6,14]$.

On the other hand, the resource dependence theory suggests the importance of resources, discretion over their use and distribution, their alternative possibility, and their possession as a component of resource dependency [20, 27]. In particular, first, the importance of resources is a measure that an organization places emphasis on resources of the other. Second, the discretion over the use and distribution of resources can be described as control over resources and is the authority for the use and distribution of organizational resources. When one organization has the ability to access its own resources, control them, and make regulations, the organization that needs these resources comes to depend on the organization that possesses them.

Third, the alternative possibility of resources can be expressed as a concentration of resource control and is an alternative measure of the ability of organizations to substitute one source of resources for another. This is related to the number of other organizations that provides the organization with resources. When the number is small, the organization becomes highly dependent on resources of the other because it has less resources to substitute. Finally, the possession of resources is the resource possession of the organization. The organization becomes highly dependent on resources of the other because when it possesses less resources.

\subsection{Tourism Development and Resource Dependency}

The resource dependency in tourism development of local governments has similarities with the resource dependency of companies and also has significant differences. First, it includes resource dependence factors theory applied to the corporate sector such as the importance of resources, discretion over their use and distribution, and alternative possibility. This is because the common organizational characteristics are reflected in local governments and companies. In particular, the prerequisites for organizational resource dependency in the corporate sector suggested by resource dependence theory, which are mutual exchange of interorganizational resources, resource constraint, incomplete transfer and imitation of resources, recognition of resource value by other organizations [24 - 27] correspond to local governments to implement tourism development $[5,16,29]$. 
Subsequently, the most significance difference between the corporate sector and the tourism developments of local governments is the connection of resources. Unlike manufacturers, local governments need resources such as natural and cultural resources for their tourism development [7, $21,23]$. Therefore, the obtained resources are frequently shared with other local governments. For successful tourism development, local governments have recognized the need for geographical and spatial connections [12-13] and cultural connection [17] and become highly dependent in connection with the other local governments.

Furthermore, the level of possession of resources is an important factor in tourism development of local governments as well as in resource dependence theory. According to the study by Sohn \& Kim [29], the level of possession of resources was set as an organizational environment factor and had an effect on the interaction of local governments.

\section{Research Methods}

\subsection{Measurement of the Resource Dependency}

In order to measure the resource dependency of tourism development, this study derived a total of 17 measurement items based on resource dependence theory and literature related to tourism development and resource dependency (see Table 1).

\subsection{Respondents and Analysis Methods}

The questionnaire respondents were 22 civil servants of the seven local governments that participated directly in the Jirisan area tourism development project. This study aimed to derive the factors of resource dependency based on an analysis of the results to an attitude survey. This was the only source of data since it was not possible to collect secondary data to measure resource dependency. Furthermore the respondents had enough knowledge related to the primary factor, which was cooperation.

In consideration of the relationship between the local governments related to the Jirisan area multiregional tourism development, the questionnaire consisted of a total of 17 items so that the civil servants of local governments could indicate the level of dependency. The number of the questionnaire that the civil servants responded to varied according to the number of detailed projects they participated in. They responded to seven items on average.

180 questionnaires were collected out of the distributed 264. Out of these a total of 166 were used in the analysis.

Table 1. Measurement Items of Resource Dependency

\begin{tabular}{|c|c|}
\hline Measurement Items & related literature \\
\hline Possession level of tourism development resource & Ahn [1], \\
Possession level of tourism resource & Kim, Chae, Choi \& Kim [11], \\
Possession level of tourism resource facilities & Sohn \& Kim [29], \\
Possession level of tourism financial resource & Pfeffer \& Salancik [24], \\
Possession level of tourism organizational resource & Ring [25], \\
\hline
\end{tabular}




\begin{tabular}{|c|c|}
\hline $\begin{array}{c}\text { Proportion of tourism project } \\
\text { Utility of tourism project } \\
\text { Necessary of tourism project success }\end{array}$ & Skinner, Gassenheimer \& Kelly [30] \\
\hline Actual use authority & \\
Access control authority \\
Norms-making authority \\
\hline Alternative to local government \\
Alternative to other local government \\
Difficulty of tourism project \\
Similarity \\
Complementarities & Kim [9], Shin [12], \\
\hline
\end{tabular}

\section{Analysis Results}

\subsection{Derivation of Resource Dependency Factors}

In this study, a factor analysis was conducted to derive factors of resource dependency. As a result, a total of five factors were derived. Based on previous studies on resource dependence theory, the derived factors of resources were named as possession, importance, connection, discretion, and alternative. The total variance explanatory power of the five factors was $76.69 \%$, and the KMO value was 0.651 . According to Bartlett's test of sphericity, the validity was demonstrated $(\mathrm{x} 2=1439.545$, $\mathrm{p}<.000$ ). All Cronbach's alpha values were more than 0.6 , and the reliability was examined (refer to Table 2).

Table 2. Factor Analysis Results of Resource Dependency

\begin{tabular}{|c|c|c|c|c|c|c|}
\hline Factor & Variable & $\begin{array}{l}\text { Factor's } \\
\text { Loading }\end{array}$ & $\begin{array}{l}\text { Commun- } \\
\text { ality }\end{array}$ & $\begin{array}{l}\text { Eigen } \\
\text { Values }\end{array}$ & $\begin{array}{l}\text { Variance } \\
\text { Explanatory } \\
\text { Power }\end{array}$ & $\begin{array}{c}\text { Cronbach's } \\
\alpha\end{array}$ \\
\hline \multirow[t]{4}{*}{ Possession } & $\begin{array}{l}\text { Possession level of tourism } \\
\text { resource }\end{array}$ & .902 & .894 & \multirow[t]{4}{*}{3.927} & \multirow[t]{4}{*}{25.122} & \multirow[t]{4}{*}{.894} \\
\hline & $\begin{array}{l}\text { Possession level of tourism } \\
\text { resource facilities }\end{array}$ & .877 & .806 & & & \\
\hline & $\begin{array}{c}\text { Possession level of tourism } \\
\text { development resource }\end{array}$ & .870 & .840 & & & \\
\hline & Possession level of tourism & .775 & .689 & & & \\
\hline
\end{tabular}




\begin{tabular}{|c|c|c|c|c|c|c|}
\hline & financial resource & & & & & \\
\hline & $\begin{array}{l}\text { Possession level of tourism } \\
\text { organizational resource }\end{array}$ & .743 & .716 & & & \\
\hline \multirow{3}{*}{ Importance } & Proportion of tourism project & .865 & .809 & \multirow{3}{*}{2.961} & \multirow{3}{*}{16.041} & \multirow{3}{*}{.839} \\
\hline & $\begin{array}{l}\text { Necessary of tourism project } \\
\text { success }\end{array}$ & .860 & .794 & & & \\
\hline & Utility of tourism project & .841 & .756 & & & \\
\hline \multirow{3}{*}{ Connection } & Ease of use in common & .814 & .758 & \multirow{3}{*}{1.140} & \multirow{3}{*}{11.023} & \multirow{3}{*}{.663} \\
\hline & Complementarities & .738 & .753 & & & \\
\hline & Similarity & .724 & .640 & & & \\
\hline \multirow{3}{*}{ Discretion } & Norms-making authority & .876 & .812 & \multirow{3}{*}{1.949} & \multirow{3}{*}{12.369} & \multirow{3}{*}{.791} \\
\hline & & & & & & \\
\hline & Access control authority & .862 & .816 & & & \\
\hline \multirow{3}{*}{ Alternative } & Difficulty of tourism project & .824 & .693 & \multirow{3}{*}{1.526} & \multirow{3}{*}{12.130} & \multirow{3}{*}{.626} \\
\hline & & & & & & \\
\hline & $\begin{array}{l}\text { Alternative to other local } \\
\text { government }\end{array}$ & .809 & .727 & & & \\
\hline
\end{tabular}

\subsection{Analysis of Resource Dependency Level in the Multi-Regional Tourism Development}

Based on the results, the level of resource dependency in the Jirisan area tourism development project is shown in Table 3. Although the mean value of resource dependency is at a low level, 2.84 points, possession (3.26 points) and connection (3.13 points) that highly reflect the main characteristics of tourism development are relatively high.

This study examined differences in resource dependency according to tourism development project scale. It was found that there was no significant difference in resource dependency between large- and small-scale products. However, there are significant differences in the detailed factor importance of resources, and large scale projects show greater importance of resources than small scale ones.

This study examined differences in resource dependency according to visitor scale. As a result, there was no significant difference in resource dependency between local governments with large and small visitors. However, there are significant differences in the detailed factor analysis. With regard to the possession and importance of resource dependency, local governments with more visitors show higher dependency. With regard to the alternative of resources, local governments with fewer visitors show higher dependency (see Table 3). 
SHS Web of Conferences

Table 3. Resource Dependency Mean Comparison according to Project and Visitor's Scale

\begin{tabular}{|c|c|c|c|c|c|c|c|}
\hline & & & roject $S$ & & & isitor $\mathrm{S}$ & \\
\hline & $(n=166)$ & $\begin{array}{c}\text { Small } \\
(\mathrm{n}=118)\end{array}$ & $\begin{array}{l}\text { Large } \\
(\mathrm{n}=48)\end{array}$ & t-value(p) & $\begin{array}{l}\text { Small } \\
(\mathrm{n}=71)\end{array}$ & $\begin{array}{l}\text { Large } \\
(\mathrm{n}=95)\end{array}$ & t-value(p) \\
\hline Possession & 3.26 & 3.26 & 3.25 & .100 & 2.98 & 3.46 & $-4.036 * *$ \\
\hline $\begin{array}{l}\text { Possession level of tourism } \\
\text { development resource }\end{array}$ & 3.40 & 3.36 & 3.50 & -.878 & 3.14 & 3.60 & $-3.347 * *$ \\
\hline $\begin{array}{l}\text { Possession level of tourism } \\
\text { resource }\end{array}$ & 3.39 & 3.36 & 3.48 & -.745 & 3.01 & 3.67 & $-4.619 * *$ \\
\hline $\begin{array}{l}\text { Possession level of tourism } \\
\text { resource facilities }\end{array}$ & 3.28 & 3.35 & 3.10 & 1.246 & 2.85 & 3.60 & $-4.446 * *$ \\
\hline $\begin{array}{l}\text { Possession level of tourism } \\
\text { financial resource }\end{array}$ & 2.96 & 2.92 & 3.06 & -1.032 & 2.56 & 3.26 & $-6.313 * *$ \\
\hline $\begin{array}{l}\text { Possession level of tourism } \\
\text { organizational resource }\end{array}$ & 3.24 & 3.31 & 3.08 & 1.523 & 3.35 & 3.16 & 1.454 \\
\hline Importance & 2.78 & 2.71 & 2.94 & $-2.304^{*}$ & 2.57 & 2.93 & $-3.926^{* *}$ \\
\hline Proportion of tourism project & 2.64 & 2.51 & 2.98 & $-3.975 * *$ & 2.31 & 2.89 & $-5.622 * *$ \\
\hline Utility of tourism project & 2.89 & 2.87 & 2.94 & -.605 & 2.82 & 2.95 & -1.338 \\
\hline $\begin{array}{l}\text { Necessary of tourism project } \\
\text { success }\end{array}$ & 2.80 & 2.75 & 2.92 & -1.363 & 2.59 & 2.95 & $-3.171 * *$ \\
\hline Discretion & 2.63 & 2.58 & 2.76 & -1.852 & 2.58 & 2.66 & -.856 \\
\hline Access control authority & 2.72 & 2.65 & 2.90 & $-2.156^{*}$ & 2.66 & 2.77 & -1.018 \\
\hline Norms-making authority & 2.54 & 2.50 & 2.63 & -1.180 & 2.51 & 2.56 & -.522 \\
\hline Alternative & 3.04 & 3.02 & 3.08 & -.545 & 3.44 & 2.74 & $7.948 * *$ \\
\hline $\begin{array}{c}\text { Alternative to other local } \\
\text { government }\end{array}$ & 3.19 & 3.17 & 3.25 & -.570 & 3.63 & 2.86 & $6.718^{* *}$ \\
\hline Difficulty of tourism project & 2.89 & 2.87 & 2.92 & -.348 & 3.25 & 2.61 & $6.185^{* *}$ \\
\hline Connection & 3.13 & 3.11 & 3.17 & -.575 & 3.13 & 3.13 & .051 \\
\hline Similarity & 3.43 & 3.53 & 3.19 & $2.663^{* *}$ & 3.55 & 3.35 & 1.673 \\
\hline Complementarities & 3.13 & 3.08 & 3.25 & -1.137 & 2.93 & 3.28 & $-2.712 * *$ \\
\hline Ease of use in common & 2.82 & 2.71 & 3.08 & $-2.538^{*}$ & 2.92 & 2.75 & 1.235 \\
\hline
\end{tabular}

$* *: \mathrm{p}<0.01, *: \mathrm{p}<0.05$ 


\section{Conclusions \& Discussions}

The purpose of this study was to derive multidimensional attributes of resource dependency of local governments in multi-regional tourism development. The measurement items of resource dependency consisted mainly of the analysis of resource dependence theory and related literature. The factors of resource dependency were derived by analysis of the questionnaire for the civil servants who participated in the Jirisan area tourism development project which is a representative multi-regional tourism development project of Korea. The five derived factors consisted of possession, importance, discretion, alternative, and connection. Among them, connection is the factor that is most characteristic of resource dependency for tourism projects. This finding differentiates this study from the results of previous studies on resource dependency between companies.

The measured values by factor vary according to project scale and visitors in tourism development projects. Local governments with large scale projects and visitors show higher measured values than those with fewer visitors. On the other hand, in the alternative factor, local governments with fewer visitors show higher measured values than those with more visitors. These results suggest that various variables have an effect on resource dependency.

These results extend the application of resource dependence theory in tourism development. Specifically, this study revealed that connection among resources should be added to factors of resource dependency suggested in corporate sector [24].

This study is significant in that it empirically demonstrates the relevance of resource dependency theory, previously only applied to private companies, to the domain of tourism projects conducted by local governments. In the future, it will be necessary to find methods capable of compensating for the lack of attitude surveys by the analysis of secondary data drawn from a greater variety of sources related to resource dependency. It would also be beneficial to draw responses from a larger pool of respondents.

\section{References}

1. J. S. Ahn, Determinants of Governance Structure in International Joint-Ventures, Korean Academy of International Business, 367-390 (1996)

2. H. Aldrich, Resource Dependence and in Terorganiza Tional Relations Local Employment Service Offices and Social Services Sector Organizations. Administration \& Society, 7 (4) ,419-454 (1976)

3. S. S. Andaleeb, Dependence Relations and the Moderating Role of Trust; Implications for Behavioral Intentions in Marketing Channels. International Journal of Research in Marketing, 12, 2, 157-172 (1995)

4. S. S. Andaleeb, An Experimental Investigation of Satisfaction and Commitment in Marketing Channels; The Role of Trust and Dependence. Journal of retailing, 72, 1, 77-93 (1996)

5. J. E. Choi, Exploratory Research on the Policy Suggestions of Multi-Regious Tourism Development Plan. Northeast Asia Tourism Research, 7, 2, 69-90 (2011)

6. J. W. Choi, Evolutionary Process Analysis of Government-Firms Relationship in Korea, Journal of Public Administration, 37, 1, 137-174 (1999)

7. C. A. Gunn, Tourism Planning (2nd ed.). New York: Taylor and Francis, (1988)

8. S. D. Jap, S. Ganesan, Control Mechanisms and the Relationship Lifecycle: Implications for Safeguarding Specific Investments and Developing Commitment, Journal of Marketing Research, 37, 2, 227-245 (2000)

9. K. C. Kim, The Change of $4 S$ 's Economics Concept and Linkage Competitiveness, Korean Journal of Marketing, 1, 1,C1-C26 (1998)

10. B. M. Kim, Tourism Resource, Seoul: BaekSan Press, (1995).

11. S. E. Kim, W. H. Chae, J. H. Choi, \& S. K. Kim, Study of Cooperation among Local

12. Y. Y. Kim, Y. S. Shin, Exploratory Research on Network-Centric Tourism Development as an Alternative to Multi-Regional Tourism Planning, Seoul City Research, 11, 3, 123-138 (2010) 
13. W. J. Kim, H. C. Hong, The Spatial Linkage and Behavior Characteristics of Multi Destination Trip in the Eastern Part of the Gyeonggi Province, Journal of Tourism Sciences, 30, 3, 267-291 (2006)

14. J. K. Kim, A Model of Government-NGO Relationship: From the Resource Dependency Perspective, Journal of the Korean Association for Policy Studies, 9, 2, 5-28 (2000)

15. K. D. Kwon, S. H. Lee, An Empirical Study on Cooperation between Business and Large Firms: Focused on the Dependence, Power and Trust, The Journal of Entrepreneurship and Venture Studies, 6, 2, 53-75 (2003)

16. Y. J. Lee, S. D. Choi, Conceptual Study on the Characteristics of Tourism Industrial Clusters, Journal of Tourism Studies, 15, 47-66 (2003)

17. H. J. Lee, The Connection Method between Local Festival and Cultural Tourism Resource, The Research Institute of Paekche Culture, 27, 139-152 (1998)

18. Ministry of Culture, Sports and Tourism, The Third Tourism Development Master Plan, (2011),

19. Ministry of Culture, Sports and Tourism, Annual Report according 2012 Tourism Trends, (2013),.

20. W. Nienhueser, Resource Dependence Theory-How Well Does It Explain Behavior of Organizations. management revue. The International Review of Management Studies, 19,1, 9-32 (2008)

21. S. H. Park, New Tourism Resources, Seoul: DaeWang Press, (2012)..

22. H. H. Park, G. O. Jung, S. C. Lee, A Study of the Factors Influencing on Manufaturer's Private Brand Dependence and Long-term Relationship with Retailer, Korean Marketing Review, 26, 4, 77-106 (2011)

23. D. G. Pearce, Tourist development. London: Longman Group Limited, (1981)

24. J. Pfeffer, G. R. Salancik, The External Control of Organizations: A Resource Dependence Perspective, New York: Harper \& Row, (1978)

25. P. S. Ring, Networked Organization: A Resource-Based Perspective. Uppsala: University press, (1996)

26. D. L. Roger, D. A. Whetten, Interorganization Relationships: Patterns and Motivations. Administrative Science Quarterly, 22, 2, 220-234 (1982)

27. F. W. Scharpf, Interorganizational Policy Studies: Issues, Concepts and Perspectives In K. Hanf $W$. Scharpf(ed.), Interorganizational policy making: limits to coordination and central control. Beverly Hills, CA: Sage Publications, (1978).

28. R. W. Scott, Organizations: Rational, Natural, and Open Systems. Englewood Cliffs, New Jersey: Prentice-Hall, (1981)

29. D. H. Sohn, J. H. Kim, The Study on the Inter-Organizational Relations of Local Government Tourism Administration, Korean Journal of Tourism Research, 13, 119-141 (1999)

30. S. J. Skinner, J. B. Gassenheimer \& S. W. Kelly, Cooperation in Supplier-dealer Relations. Journal of Retailing, 68, 2, 174-193 (1992) 